\title{
Makna Pesan Sosial dalam Iklan Layanan Masyarakat "Stereotip Z": Sebuah Kajian Semiotika Riffaterre
}

\author{
Budi Santoso ${ }^{1}$, Andi Hallang Lewa ${ }^{2}$ \\ Jurusan Bahasa dan Sastra Jepang, Universitas Dian Nuswantoro \\ budi.santoso@dsn.dinus.ac.id
}

\begin{abstract}
Public service advertising "Stereotype $Z$ " is public service advertising that explain the negative effects of gadgets on adolescent behavior. This study aims to describe the meaning of social messages in the text of public service advertising "Stereotip Z". Descriptive qualitative method is used in the research. The data was taken from the text of public service advertisement "Steoretip Z". Data analysis use Riffaterre's semiotic approach with focus on analysis of heuristic and hermenetic reading, analysis of the indirect expressions, analysis of matrix, model, variant, and analysis of hypogram. Results of analysis show that the text of public service advertising "Stereotype Z" contains a social message that persuade the young generation (generation Z) to be more critical about the problems in their suroundings.
\end{abstract}

Keywords: Social message; public service advertising; stereotip Z.

\section{Intisari}

Iklan layanan masyarakat "Stereotip Z" merupakan iklan layanan masyarakat yang menjelaskan efek negatif gadget pada perilaku remaja. Penelitian ini bertujuan mendeskripsikan makna pesan sosial dalam teks iklan layanan masyarakat "Stereotip Z". Metode kualitatif deskriptif digunakan dalam penelitian. Data diambil dari teks iklan layanan masyarakat "Steoretip Z". Analisis data menggunakan ancangan semiotika Riffaterre dengan fokus pada analisis pembacaan heuristik dan hermenetic, analisis ketidaklangsungan ekspresi, analisis matriks, model, varian, serta analisis hipogram. Hasil analisis menunjukkan bahwa teks iklan layanan masyarakat "Stereotip Z" mengandung pesan sosial menganjak generasi muda (generasi Z) untuk menjadi lebih kritis terhadap permasalahan di lingkungan sekitar mereka

Kata kunci: Social message; public service advertising; stereotip Z.

\section{Pendahuluan}

Saat ini, hampir setiap orang memiliki gadget. Dimanapun, kapanpun gadget tak pernah lepas dari tangan mereka. Gadget bukan sekedar alat berkomunikasi, tapi sudah menjadi simbol identitas diri, lifestyle (gaya hidup), tren, dan prestise (Kagoya, 2015). Terjadi perubahan gaya hidup terhadap para pemegang gadget. Orang lebih disibukkan dengan gadget atau smartphonenya dibandingkan harus berinteraksi dengan lawan bicara atau 
Budi Santoso dan Andi Hallang Lewa, Makna Pesan Sosial dalam Teks Iklan Layanan Masyarakat "Stereotip Z: Sebuah Kajian Semiotik Riffaterre

membangun hubungan dengan lingkungan (Marpaung, 2018). Pada kalangan remaja, dampak negatif tampak pada perubahan perilaku yang ditunjukkan mereka seperti menjadi introvet, sulit konsentrasi pada dunia nyata, suka selfi, anti sosial, dan penyimpangan sosial (Arifin, 2015). Melihat kondisi tersebut, pemerintah tentunya tidak tinggal diam. Berbagai usaha dilakukan untuk mencegah meluasnya dampak negatif gadget di kalangan remaja.

Salah satu usaha yang dilakukan adalah dengan menyadarkan remaja akan bahaya gadget melalui iklan layanan masyarakat. Iklan layanan masyarakat (ILM) merupakan iklan non komersil yang berisi pesan sosial berupa ajakan, pernyataan atau himbauan kepada masyarakat untuk melakukan suatu tindakan yang merubah perilaku menjadi lebih baik (Kasali, 1992). Iklan dibuat sedemikian rupa, menarik, unik, dan mudah dipahami sehingga pesan sosial iklan tersampaikan kepada masyarakat. Pesan-pesan sosial iklan diwujudkan dalam bentuk sebuah teks. Pengertian lebih sempit tentang teks merujuk pada pesan-pesan tertulis, sedangkan dalam arti luas teks didefinisikan sebaga pesan-pesan baik yang menggunakan tanda verbal berupa teks lisan dan teks tertulis maupun tanda visual yang berupa gambar, foto, ctra rekaan komputer dll. (Piliang, 2004).

Iklan layanan masyarakat "Stereotip Z" merupakan salah satu contoh iklan ILM yang mengajak remaja yang sudah kecanduan gadget untuk berubah menjadi lebih baik. Hal yang menarik dari iklan ini adalah cara penyampaian pesan teks yang berbeda dengan ILM pada umumnya. Pada umumnya ILM menyampaikan pesan sosial dalam bentuk naratif drama dan menggunakan bahasa sehari-hari yang mudah dipahami. Pesan teks ILM "Stereotip Z" disampaikan dalam bentuk baris dan bait layaknya puisi sehingga untuk memahami pesan sosial yang terkandung di dalamnya perlu penelaahan lebih mendalam. Penelitian tentang makna pesan sosial ILM (Mustika, 2016; Santoso, 2018; Suarjana \& Suwitra, 2018), umumnya dilakukan melalui pendekatan semiotika komunikasi dengan menelaah tanda verbal dan tanda visual yang membentuk iklan. Berbeda dengan penelitian sebelumnya, pada penelitian ini, penulis melakukan penelitian terhadap pesan sosial yang ada pada ILM "Stereotip Z" dengan pendekatan semiotik Riffaterre. Semiotik Riffaterre, sendiri sebagian besar digunakan oleh para peneliti untuk menelaah puisi (Diana, 2018; Hasanah, 2018; Lestari, 2020) maupun lagu (Saadah, 2018; Herlinda, 2018). Pemilihan semiotika Riffaterre sebagai pendekatan penelitian sesuai dengan topik penelitian mengingat teks verbal dalam ILM menggunakan bentuk 
penyampaian bahasa yang mirip dengan puisi. Selain itu, jarang ditemukan penggunaan pendekatan semiotik puisi untuk menelaah teks ILM.

Nasution (2014) mengemukakan bahwa semiotika adalah ilmu yang secara sistematik mempelajari tanda-tanda. Dalam sebuah teks, tanda-tanda diwujudkan dalam bentuk bahasa. Ratih (2016) menyatakan bawa puisi merupakan aktivitas bahasa yang berbeda dengan pemakaian bahasa pada umumnya. Puisi senantiasa berbicara mengenai sesuatu secara tidak langsung dengan menyembunyikannya ke dalam suatu tanda. Hal ini mengindikasikan bahwa ketidaklangsungan menjadi ciri utama puisi. Dalam memproduksi makna puisi, Riffatarre (1978) mengemukakan adanya empat hal yang harus dipahami yaitu; (a) pembacaan heuristik dan hermenetik, (b) puisi diekspresikan tidak langsung, (c) maktriks, model dan varian-varian, dan (d) hiprogam. Pembacaan hermeneutik, merupakan pembacaan tingkat kedua dengan melakukan pembacaan ulang dari awal sampai akhir yang diikuti suatu penafsiran (Pradopo, 2010). Ketidaklangsungan ekspresi puisi terjadi karena adanya penggantian arti (displacing of meaning), penyimpangan arti (distorsing of meaning), dan penciptaan arti (creating of meaning). Penggantian arti terjadi melalui penggunaan suatu kata kiasan. Penyimpangan arti muncul karena adanya ambiguitas, kontradiksi atau ironi, dan nonsense. Penciptaan arti dapat diketahui melalui keseimbangan (simitri), rima, peloncatan sintaksis (enjambemen), serta persamaan posisi (homologues).

Matriks merupkan kata kunci yang memberikan makna kesatuan sebuah puisi (Riffaterre,1978). Puisi dihasilkan dari tranformasi matriks berupa kata, kelompok kata, atau kalimat sederhana menjadi sebuah wacana yang lebih panjang, kompleks, dan nonliteral. Matriks dapat dilambangkan dengan satu kata yang tidak muncul dalam teks. Matrik kemudian dijabarkan menjadi model. Model berupa satu kata atau kalimat yang bersifat puitis dan menjadi aktualisasi dasar pertama dalam menentukan varian. Dalam hal ini, Varian-varian tersebut bisa dikatakan sebagai penjabaran model yang terdapat pada setiap bait atau baris puisi (Arwan \& Ukhrawiyah, 2019).

Hipogram atau hubungan intertekstual adalah teks yang menjadi latar penciptaan teks lain (Pradopo 2010). Pada proses penciptaan dan pembacaan karya sastra, keberadaan suatu teks tidak dapat dilakukan tanpa adanya teks-teks lain sebagai contoh, teladan, kerangka dan seterusnya (Teeuw, 1984). Senada dengan Teeuw, Kristeva (1980) menyatakan bahwa intertekstualitas adalah hakekat suatu teks yang di dalamnya ada teks lain yang saling menyilang dan menetralisir satu sama lain. Dalam hal ini, pemahaman 
Budi Santoso dan Andi Hallang Lewa, Makna Pesan Sosial dalam Teks Iklan Layanan Masyarakat "Stereotip Z: Sebuah Kajian Semiotik Riffaterre

terhadap teks baru memerlukan latar belakang pengetahuan tentang teks-teks lain yang mendahuluinya

Penelitian ini bertujuan untuk mendeskripsikan pesan sosial pada ILM "Stereotip Z" dengan pendekatan semiotik Riffaterre. Adapun permasalahan yang akan diteliti adalan apakah pesah sosial yang ingin disampaikan oleh ILM "Stereotip Z". Agar pembahasan tidak terlalu luas, maka pembahasan penelitian ini dibatasi pada masalah pesan sosial yang ada pada teks verbal ILM "Stereotip Z".

\section{Metode Penelitian}

Penelitian ini merupakan penelitian deskriptif kualitatif. Metodologi deskriptif kualitatif yaitu suatu bentuk penelitian yang bertujuan untuk mendeskripsikan fenomena-fenomena yang ada, baik fenomena alamiah maupun fenomena buatan manusia (Sukmadinata, 2006). Bogdan dan Taylor (1992) mengemukakan bahwa penelitian kualitatif adalah salah satu prosedur penelitian yang menghasilkan data deskriptif berupa ucapan atau tulisan. Pada penelitian ini, analisis data yang dihasilkan adalah narasi deskriptif pesan yang ingin disampaikan oleh teks iklan layanan masyarakat "Stereotip Z".

Sebagai sumber data utama penelitian digunakan ILM "Stereotip Z” yang diambil dari situs https://www.youtube.com/watch?v=VqmM3sKxm3Y. Subandi (2011) menyatakan bahwa sumber data utama dalam penelitian kualitatif adalah kata-kata dan tindakan, Iklan layanan masyarakat "Stereotip Z" dipilih dengan pertimbangan iklan tersebut berkualitas dan mengandung pesan yang baik. Hal ini dibuktikan dengan diberikannya penghargaan sebagai juara pertama kepada iklan layanan masyarakat "Stereotip Z" dalam ajang kompetisi iklan layanan masyarakat yang diselenggarakan oleh Kemendikbud RI tahun 2019. Teknik pengumpulan data menggunakan teknik dokumen dengan cara mengumpulkan berbagai literatur tertulis yang berkaitan dengan topit penelitian.

Semiotika Puisi Riffaterre digunakan sebagai ancangan penelitian dalam menganalisis tanda. Adapun langkah analisis data ditempuh sesuai dengan langkah analisis pemaknaan puisi dari Riffaterre, yaitu:

1. Melakukan pambacaan heuristik dan hermenetik terhadap teks ILM "Steoretip Z" 
Budi Santoso dan Andi Hallang Lewa, Makna Pesan Sosial dalam Teks Iklan Layanan Masyarakat "Stereotip Z: Sebuah Kajian Semiotik Riffaterre

2. Menentukan ketidaklangsungan ekspresi yang ada dalam teks ILM "Steoretip Z" melalui penggantian arti, penyimpangan arti, dan penciptaan arti

3. Menentukan matriks, model, dan varian teks ILM "Steoretip Z"

4. Menentukan hipogram teks ILM "Steoretip Z”

\section{Hasil dan Pembahasan}

\section{Pembacaan Heuristik dan Hermeneutik}

Pembacaan heuristik sajak didasarkan pada konvensi bahasa sesuai dengan kedudukan bahasa sebagai sistem semiotik tingkat pertama. Pembacaan heuristik terhadap teks ILM "Steoretip Z" menunjukkan bahwa pada bagian awal hingga pertengahan iklan (baris 113)- bercerita tentang pendapat negative masyarakat umum terhadap generasi $Z$ atau bisa disebut generasi gadget. Setengah bagian terakhir teks berisi ajakan kepada Generasi Z untuk berubah menjadi generasi yang lebih baik. Teks iklan ditutup dengan kalimat pertanyaan yang berupa kalimat retorika sebagai suatu bentuk perenungan bagi generasi Z. Secara lebih lengkap, keseluruhan teks Iklan Layanan Masyarakat adalah sebagai berikut.

1) Orang bilang (1)

Kita generasi yang terlahir dari tontonan (2)

Yang membuka jendela duniapun (3)

Harus dibudidayakan (4)

Lalu katanya (5)

Kita adalah generasi yang hanya bisa menunduk (6)

Saat bicara pada maya (7)

Untuk meraih masa depan (8)

Dan (9)

Terjebak pada mayoritas yang diam (10)

Pada akhirnya (11)

Menjadi generasi yang hanya diam (12)

Dan tak bias berkomentar (13)

Coba peka (14)

Mari (15)

Tunjukkan pada dunia (16)

Bahwa kita generasi yang bias berpendapat (17)

Agar tahu (18)

Apa yang kita cari (19)

Sebenarnya (20)

Ada di depan mata (21)

Mulai membuka diri (22) 
Budi Santoso dan Andi Hallang Lewa, Makna Pesan Sosial dalam Teks Iklan Layanan Masyarakat "Stereotip Z: Sebuah Kajian Semiotik Riffaterre

Pada luasnya dunia (23)

Lalu berani berbalik (24)

Dan mengambil jalan sendiri (25)

Ke garis akhir lebih awal (26)

Sudahkah lebih baik (27)

Baris (1) sampai baris (4) mengambarkan pendapat masyarakat yang menganggap generasi $\mathrm{Z}$ sebagai generasi yang dilahirkan dan hidup dalam dunia hiburan (entertainment). Kebiasaan menonton hiburan melalui gadget ataupun smart phone membuat mereka sibuk dengan dunianya sendiri dan tidak peduli dengan kondisi di luar dunianya (lingkungan sekitarnya). Jika ingin membuat mereka memperhatikan lingkungan sekitarnya, maka nilai-bilai kepedulian social harus ditanamkan. Pandangan negative lain terhadap generasi $\mathrm{Z}$ dijelaskan lebih lanjut pada baris (5-8) yang mengambarkan kebiasaan mereka yang selalu menunduk dan memandang gadget saat berinterakasi di dunia maya karena bagi mereka di sanalah terdapat masa depan. Baris (913) menggambarkan akibat kebiasaan Generasi $Z$ yang disibukkan dengan gadgetnya yaitu dengan menyatakan bahwa mereka terperangkap ke dalam kelompok orang yang hanya bisa diam sehingga membuat mereka menjadi generasi yang diam dan tidak bisa memberikan komentar pada permasalahan di dunia luar.

Setengan bagian teks selanjutnya (baris 14-27) menggambarkan ajakan kepada generasi $\mathrm{Z}$ untuk berubah menjadi generasi yang lebih peka, kritis dan mengambil langkah yang berlwanan dengan anggapan masyarakat umum. Kalimat baris (14) berisi anjuran yang dilanjutkan dengan ajakan pada baris (15-21) untuk menunjukkan dan membuktikan diri pada masyarakat bahwa mereka adalah generasi yang bisa memberikan pendapat kritis terhadap permasalahan yang ada di sekitarnya dan akan membuat mereka sadar bahwa hal yang mereka cari ada di sekitarnya (dunia nyata) bukan di dunia maya (dunia internet). Ajakan perubahan lebih lanjut ditunjukkan dalam baris (16-26). Baris (16-26) berisi ajakan kepada generasi $\mathrm{Z}$ untuk membuka diri dan pikirannya terhadap hal-hal di dunia nyata, meninggalkan jalan kelompok orang yang diam dan tidak peduli untuk selanjutnya mengambil jalan sendiri untuk mengejar cita-cita mereka. Dengan demikian, mereka akan mencapai tujuan dan cita-cita mereka lebih cepat dari kelompok orang-orang yang diam. Kalimat penutup teks "Sudahkah lebih baik" pada baris (27) merupakan kalimat retorika yang berfungsi sebagai bentuk perenungan bagi Generasi $\mathrm{Z}$ apakah 
Budi Santoso dan Andi Hallang Lewa, Makna Pesan Sosial dalam Teks Iklan Layanan Masyarakat "Stereotip Z: Sebuah Kajian Semiotik Riffaterre

mereka sudah menjadi generasi yang lebih baik atau masih sama seperti anggapan masyarakat umum.

Pembacaan secara hermenetik melibatkan makna yang lebih mendalam terhadap kata-kata yang digunakan dalam teks iklan layanan masyarakat "Stereotip Z". Beberapa kata dalam teks tidak bisa diartikan secara literal tetapi harus ditelaah lebih mendalam sehingga ditemukan makna sebenarnya yang ingin disampaikan oleh penulis teks. Pada kalimat (2) misalnya kata tontonan tidak bisa dimaknai sebagai tontonan yang sebenarnya seperti film, konser dan sebagainya, tetapi harus dimaknai sebagai dunia yang penuh tontonan, dunia hiburan atau dunia entertainment. Oleh karena itu kalimat "kita generasi yang terlahir dari tontonan" bermakna bahwa kita (generasi Z) merupkan generasi yang lahir dan hidup di dunia hiburan atau entertainment. Tuturan "membuka jendela" pada baris (3) juga tidak bisa dimaknai secara literal karena dunia tidaklah punya jendela. Kata "membuka jendela" dimaknai sebagai melihat karena tuturan "membuka jendela dunia" merijuk pada makna melihat dunia luar di sekitarnya.

Kata "maya" pada baris (7) tidak merujuk pada nama seseorang tetapi merujuk pada dunia maya atau dunia internet, kata "diam" pada baris (10) dan (12) bukan hanya merujuk pada makna tidak bicara tetapi merujuk pada makna memberikan pendapat dan komentar yang kritis terhadap masalah di sekitarnya. Kata "di depan mata" pada kalimat (20) bukan hanya merujuk pada objek yang ada di depan atau di hadapan kita tetapi merujuk pada makna yang lebih luas yaitu segala sesuatu yang ada di dekat kita. Oleh karena itu kata "di depan mata" dimaknai sebagai segala sesuatu di dekat kita. Kata "garis akhir" pada baris (26) tidak merujuk pada makna literal seperti garis finish pada dalam perlombaan lari tetapi merujuk pada tujuan yang ingin dicapai atau cita-cita.

Pembacaan secara hermenetik menghasilkan bentuk pemahaman menyeluruh terhadap apa yang sebenarnya ingin disampaikan oleh teks iklan layanan masyarakat "Stereotip Z". Dalam hal ini, pembacaan hermenitik menghasilkan pemahan bahwa masyarakat beranggapan generasi muda sekarang (generasi Z) merupakan generasi yang bersikap individualis, tidak mau melihat dan tidak peduli kondisi lain di luar dirinya, serta tidak dapat menyumbangkan pikiran kritis terhadap berbagai masalah di lingkungan sekitarnya. Lebih lanjut, teks iklan layanan masyarakat "Stereotip Z" mengajak kepada generasi $\mathrm{Z}$ untuk berubah sikap menjadi generasi yang peka dan bisa memberikan pendapat kritis terhadap permasalahan di sekitarnya. Generasi Z harus mau membuka diri, 
Budi Santoso dan Andi Hallang Lewa, Makna Pesan Sosial dalam Teks Iklan Layanan Masyarakat "Stereotip Z: Sebuah Kajian Semiotik Riffaterre

meninggalkan jalan yang ditempuh oleh kelompok orang yang individualis dan tidak perduli, serta menentukan langkahnya sendiri untuk mencapai cita-cita yang diingikannya.

\section{Ketidaklangsungan Ekspresi}

\section{1) Penggantian Arti}

Penggantian arti ditunjukkan dengan penggunan Bahasa kiasan dalam teks. iklan layanan masyarakat "Steoretip Z" seperti dalam baris-baris berikut ini.

2) Kita generasi yang terlahir dari tontonan (2)

Yang membuka jendela duniapun (3)

Tunjukkan pada dunia (16)

Ada di depan mata (21)

Pada luasnya dunia (23)

Ke garis akhir lebih awal (26)

Sudahkah lebih baik (27)

Pada kalimat "Kita generasi yang terlahir dari tontonan" penulis menggunakan bahasa kiasan berupa majas sinekdok past pro toto dalam kata tontonan. Kata "tontonan" merujuk pada makna dunia yang penuh tontonan dan hiburan atau dunia entertainment. Dalam hal ini, kata tontonan merupakan bagian dari dunia entertainment dan digunakan sebagai kata kiasan yang mewakili keberadaan dunia entertainment dalam teks. Dengan demikian, kalimat "Kita generasi yang terlahir dari tontonan" mengandung makna kita sebagai generasi $\mathrm{Z}$ merupakan generasi yang terlahir dalam dunia yang penuh tontonan dan hiburan atau dunia entertainment.

Penggantian arti juga bisa dilihat dengan penggunaan metafora dalam tuturan "Yang membuka jendela duniapun" pada baris (3). Tuturan "membuka dunia" merupakan bentuk kiasan yang merujuk pada makna memperhatikan. Jendela merupakan bagian rumah yang digunakan oleh seseorang untuk melihat kondisi luar dari dalam rumah. Seseorang membuka jendela untuk melihat kondisi di luar rumahnya. Kata memperhatikan mengandung arti melihat dengan seksama. Oleh karena itu terdapat persamaan makna yang terkandung dalam tuturan "membuka jendela" dan kata memperhatikan yaitu tindakan melihat. Dalam hal ini, tuturan "membuka jendela" merupakan metafora bagi tindakan memperhatikan. Penggunaan kata kiasan metafora juga dapat dilihat pada baris (21) dan baris (26). Bentuk kiasan "di depan mata" merupakan metafora bagi lingkungan di sekitar kita. Tuturan "di depan mata" mengimplikasikan bahwa apa yang ada di hadapan kita jaraknya dekat sedang lingkungan sekitar kita 
Budi Santoso dan Andi Hallang Lewa, Makna Pesan Sosial dalam Teks Iklan Layanan Masyarakat "Stereotip Z: Sebuah Kajian Semiotik Riffaterre

bermakna lingkungan yang dekat dengan kita. Di sini, kita dapat melihat persamaan sifat dari tuturan "di depan mata" dan tuturan "di sekitar kita" yaitu jarak yang dekat. Tuturan "garis akhir" pada baris (26) merupakan metafora bagi cita-cita. Garis akhir bermakna garis yang menjadi tujuan akhir seperti garis finish dalam suatu perlombaan, sedangkan cita-cita mengandung makna tujuan akhir yang ingin dicapai seseorang dalam hidupnya. Di sini terdapat kemiripan arti antara kata "garis akhir" dan cita-cita yaitu tujuan akhir dari suatu tindakan.

Penggunaan bentuk kiasan lain dapat dilihat dalam kata "dunia" pada baris (16). Dalam hal ini kata dunia digunakan merujuk pada konsep dunia yang lebih sempit yaitu lingkungan sekitarnya. Lingkungan sekitar merupakan bagian dari dunia dan kata dunia digunakan untuk merujuk pada dunia yang lebih kecil sehingga bentuk kiasan yang digunakan adalah majas berupa sinekdok totem pro toto. Bentuk kiasan eufemisme digunakan dalam teks iklan layanan masyarakat "Stereotip Z" seperti terlihat dalam baris (23) dalam tuturan "luasnya dunia". Bentuk kiasan eufemisme pada tuturan "luasnya dunia" terjadi karena mengandung makna yang berlebihan. Pada kenyataannya dunia memang luas sehingga tanpa di dahului kata "luasnya" makna luas pada kata "dunia" sudah tercakup. Bentuk kiasan lain yang ada dalam teks adalah retorika. Majas retorika dapat dilihat dalam baris (27) yaitu dalam kalimat "Sudahkah lebih baik". Kalimat baris (27) berupa kalimat tanya yang berfungsi bukan untuk dijawab dengan jawaban ya atau tidak, tetapi merupakan bentuk pertanyaan untuk direnungkan oleh generasi Z. Dalam hal ini, generasi $\mathrm{Z}$ harus merenung apakah mereka sudah berubah menjadi lebih baik atau belum.

\section{2) Penyimpangan Arti}

\section{A. Ambiguitas}

Salah satu bentuk penyimpangan arti dalam ketidaklangsungan ekspresi adalah penggunaan kata-kata yang bersifat ambigu atau bermakna ganda. Dalam teks iklan layanan masyarakat "Stereotip Z", penggunaan kata ambigu dalam kalimat dapat dilihat dalam contoh berikut.

3) Harus dibudidayakan (4)

Saat bicara pada maya (7)

Menjadi generasi yang hanya diam (12) 
Pada kalimat (4) kata dibudidayakan mengandung makna yang ambigu. Kata "budi daya" bermakna usaha yang bermanfaat dan memberikan hasil dan biasanya digunakan pada bidang pertanian. Kata budidaya juga mengandung makna bahwa apa yang dilakukan dimulai sejak objeknya masih kecil (berupa bibit). Kata budi daya dalam kalimat (4) merujuk pada usaha untuk memelihara sifat atau karakter manusia yang perduli pada orang-orang lingkungan sekitarnya. Di sini, kata budi daya mengalami perubahan objek yang dirujuknya yaitu dari objek konkrit (usaha bidang pertanian) menjadi objek yang bersifat abstrak (karakter atau sifat manusia). Pada kalimat baris (7) kata "maya" mengandung makna yang ambigu. Kata "maya" bisa merujuk pada nama seorang perempuan, bisa juga bermakna dunia maya (dunia yang tidak nyata). Bila kalimat (7) diterjemahkan secara literal maka akan bermakna bahwa penulis teks berbicara dengan seseorang bernama Maya. Pemaknaan ini tentu tidak sesuai dengan apa yang ingin disampaikan iklan karena iklan tersebut berkaitan dengan kebiasaan generasi yang sibuk bermedia sosial dengan gadget. Ambiguitas juga dapat dilihat pada kata "diam" pada baris (12). Kata diam mengandung makna tidak bergerak,tidak berubah, ataupun tidak berbicara. Jika melihat pada konteks baris selanjutnya maka makna yang cocok dengan kata "diam" adalah tidak berbicara. Pelaahan lebih lanjut, terhadap kata "diam' menunjukkan bahwa apa yang dimaksud oleh kata "diam" dalam teks bukan hanya merujuk pada tidak bicara, tetapi lebih cenderung kepada makna tidak mau menyampaikan komentar kritis terhadap masalah di sekitarnya atau dengan kata lain tidak peduli.

\section{B. Kontradiksi}

Kontrakdiksi pada teks iklan layanan masyarakat "Stereotip Z" dapat dilihat pada baris (26) yaitu ke garis akhir lebih awal. Dalam baris (26) terdapat kontradiksi antara kata akhir dan awal. Kata garis akhir yang merujuk arti tujuan yang ingin dicapai digunakan memberikan nuansa puitis lebih mendalam. Kontradiksi antara kata akhir dan awal inilah yang memberikan nuansa puitis lebih mendalam dalam tuturan ke garis akhir lebih awal dibandingkan dengan tuturan mencapai tujuan lebih awal.

\section{3) Penciptaan arti.}

\section{A. Keseimbangan (simitri)}


Keseimbangan berupa persejajaran arti antara bait-bait atau antara baris-baris dalam bait.

Pada teks iklan layanan masyarakat "Streoretip Z", keseimbangan muncul dalam baris (1), (2) dan baris (5), (6) seperti berikut ini.

4) Orang bilang (1)

Kita generasi yang terlahir dari tontonan (2)

Lalu katanya (5)

Kita adalah generasi yang hanya bisa menunduk (6)

Terjebak pada mayoritas yang diam (10)

Menjadi generasi yang hanya diam (12)

Keompok data di atas menunjukkan bahwa baris (1) maupun baris (5) menyampaikan makna yang sama dan sejajar. Terjadi persamaan makna antara verba bilang dan verba kata (bentuk dasar dari verba berkata) karena bilang merupakan sinonim dari berkata. Kata orang merujuk pada objek yang sama dengan pronomina nya dalam kata "katanya". Dalam hal ini pronomina -nya merujuk pada kata orang pada baris (1) sehingga kata "katanya" dalam baris (5) bisa diganti dengan frase verbal kata orang. Dengan demikian, jelas terlihat persamaan makna antara baris (1) dan baris (5). Keseimbangan juga nampak dalam baris (2) dan baris (6) yang menggambarkan kondisi dari generasi Z. Hal ini ditunjukkan dengan penggunaan kata yang sama yaitu "Kita generasi yang" dan kemudian diikuti dengan kondisi generasi Z. Contoh lain penciptaan arti melalui keseimbangan dapat dilihat dalam baris (10) dan (12). Baris (10) dan (12) mempunyai makna yang sama yaitu menggambarkan karakter seorang atau sekelompok orang yang hanya diam atau tidak peduli terhadap permasalahan disekitarnya. Baris (10) mengambarkan kondisi generasi $\mathrm{Z}$ yang terperangkap dalam lingkungan orang yang tidak peduli dan kemudian menjadi generasi yang tidak peduli seperti tergambar dalam baris (12). Terdapat kemiripan makna antara tuturan "mayoritas yang diam" pada baris (10) dan tuturan "generasi yang hanya diam" pada baris (12) yaitu merujuk pada kelompok orang-orang yang diam atau tidak peduli.

\section{B. Perloncatan kesatuan sintaksis (enjambemen)}

Penciptaan arti melalui enjambemen terjadi ketika terjadi peloncatan sintaksis dari satu barus ke baris berikutnya. Pada iklan layanan masyarakat "Stereotip Z", peloncatan sintaksis dapat dilihat dalam baris sebagai berikut: 


\section{5) Lalu katanya (5)}

Kita adalah generasi yang hanya bisa menunduk (6)

Dan (9)

Terjebak pada mayoritas yang diam (10)

Mari (15)

Tunjukkan pada dunia (16)

Pada baris (5) dan (6) dimana frase verbal "lalu katanya" langsung diikuti oleh kalimat "Kita adalah generasi yang hanya bisa menunduk" pada baris selanjutnya. Contoh peloncatan sintaksis lainnya dapat dilihat pada baris (9) dan (10) serta baris (15) dan (16). Pada baris (9) dan (10) terjadi peloncatan sintaksis dari kata "dan" kepada frase verbal “Terjebak pada mayoritas yang diam”. Perloncatan kesatuan sintaksis pada baris (15) dan (16) terjadi karena adanya peloncatan dari kata "Mari” yang kemudian diikuti frase verbal “Tunjukkan pada dunia” pada baris berikutnya.

\section{Matriks, Model, Varian}

Matriks pada iklan layanan masyarakat "Steoretip Z" adalah generasi Z atau generasi gadget. Terdapat dua hal yang menjadi model pada teks iklan layanan masyarakat "Steoretip Z" yaitu pandangan negatif masyarakat terhadap generasi Z serta ajakan kepada generasi $\mathrm{Z}$ untuk berubah menjadi generasi yang lebih baik. Adapun varian yang terdapat dalam teks adalah:

1. Generasi $\mathrm{Z}$ adalah generasi yang lebih suka berinteraksi di dunia maya daripada berinteraksi dengan orang lain secara langsung

2. Generasi $\mathrm{Z}$ adalah generasi yang tidak perduli dengan lingkungannya

3. Generasi $\mathrm{Z}$ harus peka dan dapat membuktikan diri bahwa mereka bisa berpikir kritis

4. Generasi $\mathrm{Z}$ harus berani membuka diri segala sesuatu di lingkuangan sekitarnya serta mengambil jalan yang berbeda dan lebih baik dari orang lain untuk mengejar cita-citanya.

\section{Hipogram}

Iklan layanan masyarakat "Stereotip Z" muncul sebagai suatu bentuk anjuran kepada generasi muda saat ini atau bisa disebut generasi $\mathrm{Z}$ yang dirasa sudah terkena dampak buruk teknologi khususnya media sosial. Berbagai hal berkaitan dengan dampak buruk 
Budi Santoso dan Andi Hallang Lewa, Makna Pesan Sosial dalam Teks Iklan Layanan Masyarakat "Stereotip Z: Sebuah Kajian Semiotik Riffaterre

gadget maupun teknologi internet terhadap remaja dan generasi muda sudah banyak ditulis. Salah satu dampak buruk yang paling dapat dilihat adalah berkurangnya sikap peduli generasi muda terhadap permasalahan di sekitarnya. Kecanduan terhadap gadget dan internet berdampak buruk terhadap psikologis generasi muda. Mereka disibukkan dengan bermain gadget tanpa kenal waktu dan pada akhirnya memicu munculnya sikap yang cenderung menjauhi interaksi sosial dengan orang lain. Di sinilah kemudian tercipta bibit-bibit individualisme pada diri generasi muda. Mereka akan menjadi orang yang tidak berempati dan tidak peduli kepada permasalahan masyarakat di sekitarnya. Melihat begitu besarnya bahaya gadget terhadap psikologis generasi muda, maka berbagai pihak yang merasa khawatir (pemerintah termasuk di dalamnya) berupaya mengingatkan dampak buruk gadget dan internet kepada generasi muda. Salah satu cara yang dilakukan adalah dengan memberikan penyuluhan melalui iklan layanan masyarakat.

\section{Simpulan}

Berdasarkan hasil pembacaan heuristik dan hermenetik terhadap teks iklan layanan masyarakat "Stereotip Z" dapat disimpulkan bahwa pesan sosial yang ingin disampaikan dalam teks adalah ajakan kepada generasi $\mathrm{Z}$ untuk menjadi generasi yang lebih terbuka dan berpikir kritis. Ketidaklangsungan ekspresi dalam teks iklan layanan masyarakat "Stereotip Z" dibentuk dari penggantian arti, penyimpangan arti, dan penciptaan arti. Pengantian arti dibentuk oleh bentuk kiasan yang berupa metafora, sinekdok, eufemisme, dan retorika. Penyimpangan arti dibentuk melalui ambiguitas dan kontradiksi. Penciptaan arti teks dibentuk melalui keseimbangan (simitri) dan peloncatan sintaksis (enjambement).

Matriks dalam teks Iklan Layanan Masyarakat "Stereotip Z” adalah generasi Z. Terdapat dua model dalam teks iklan yaitu pandangan negatif masyarakat terhadap generasi $\mathrm{Z}$ dan ajakan kepada generasi $\mathrm{Z}$ untuk berubah menjadi lebih baik. Varian teks iklan terdiri dari empat varian yaitu generasi $\mathrm{Z}$ adalah generasi yang lebih suka di dunia maya, generasi $\mathrm{Z}$ adalah generasi yang tidak peduli, ajakan kepada generasi $\mathrm{Z}$ untuk berpikir kritis, dan ajakan kepada generasi $\mathrm{Z}$ untuk membuka diri dan mengambil jalan yang lebih baik. Hipogram teks menunjukkan bahwa teks Iklan Layanan Masyarakat "Stereotip Z" muncul karena adanya keprihatinan masyarakat dan pemerintah terhadap efek buruk penggunaan gadget dan teknologi internet dikalangan remaja. Penggunaan semiotik puisi Riffaterre untuk menelaah teks ILM hanyalah contoh yang membuktikan 
bahwa teks non sastrapun bisa dianalisis dengan pendekatan teori semiotika sastra. Masih banyak jenis teks diluar sastra yang bisa dianalisis dengan semiotika sastra. Akan lebih baik, jika pada peneltian selanjutnya analisis diarahkan pada jenis teks lain diluar teks iklan,

\section{Daftar Pustaka}

Arifin, Zaenal. (2015). Perilaku Remaja Pengguna Gadget: Analisis Teori Soasial Pendidikan. Tibakti: Jurnbal Pemikiran Keislaman, 26(2), 287-316.

Arwan, M. Sayyidul dan Faizatul Ukhrawiyah. (2019). Patriotisme dalam Syair Bitaqah Hawiyyah Karya Mahmud Darwisy. Jurnal Ilmiah Bahasa dan Sastra, 6(2), 6375.

Bogdan, dan Steven Taylor. (1992). Pengantar Metode Kualitatif.Surabaya: Usaha Nasional.

Diana, Jumianti. (2018). Makna Puisi Pohon Peradaban Karya Dinullah Rayes Kajian Semiotika Riffaterre. Jurnal Pena Indonesia, 4(2), 177-188.

Hasanah, Aan. (2018). Semiotika Riffaterre Puisi "Bunda Padi" Karya Al Iman dan Relevansinya dalam Pembelajaran Sastra. Semantik Journal, 7(2), 125-131

Kasali, Rhenald. (1992). Manajemen Periklanan Konsep dan aplikasinya Di Indonesia. Jakarta: Pustaka Utama Grafiti.

Kogoya, Dekinus. (2015). Dampak Penggunaan Handphone Pada Masyarakat (Studi Pada Masyarakat Desa Piungan Kecamatan Gamelia Kabupaten Lanny Jaya Papua). Jurnal Acta Diurna 4 (4).

Kristeva, J. (1980). Desire language: A semiotic to literature and art. (T. Gora, A. Jardine, dan L.S. Roudiez, penerjemah dan Leon S. Roudiez, editor). New York: Columbia University.

Lestari,Hana Putri. (2020). Semiotika Riffaterre dalam puisi "Balada Kuning-Kuning" karya Banyu Bening. Alayasastra, 16(1), 75-91.

Marpaung, J. (2018). Pengaruh Penggunaan Gadget Dalam Kehidupan. Kopasta: Jurnal Program Studi Bimbingan Konseling, 5(2), 55-64.

Herlinda,Melita. (2018). Makna pada Lirik Lagu 'Panghudang Rasa' Karya Eutik Muchtar. PANTUN, 3(2), 102-114.

Mustika, Rieka. (2016). Representasi Nilai-Nilai Edukasi pada Simbol dan Elemen Video Iklan Layanan Masyarakat Internet Sehat Aman. MTI: Jurnal Penelitian Teknologi Informasi dan Komunikasi. 7(2), 89-206.

Nasution, M. Ismail. (2014). “Semiotika”. Buku Ajar. Padang: FBS UNP.

Piliang, Yasraf Amir. 2004. "Semiotik Teks: Sebuah Pendekatan Analisis Teks". Jurnal Mediator, 5(2), 189-198. 
Budi Santoso dan Andi Hallang Lewa, Makna Pesan Sosial dalam Teks Iklan Layanan Masyarakat "Stereotip Z: Sebuah Kajian Semiotik Riffaterre

Pradopo, Rahmat Djoko. (2010). Pengkajian Puisi. Yogyakarta: Gadjah Mada University Press.

Ratih, Rina. (2016). Teori dan Aplikasi Semiotik Michael Riffaterre. Yogyakarta: Pustaka Pelajar.

Riffaterre, Michael. (1978). Semiotics of Poetry. London: Indiana of University Press.

Santoso, Budi. (2018). Analisis Makna Pesan Verbal dan Pesan Non Verbal dalam Iklan Layanan Masyarakat "STOP HOAX" RCTI". Proceeding Seminar Nasional Multi Disiplin Ilmu (SENDI-U)-4. Unisabank, Semarang. 25 Juli 2015

Saadah, Khoirus. (2018), Makna lirik lagu dalam album Ruang Tunggu karya Payung Teduh: kajian semiotika Michel Riffaterre. Jurnal Sapala, 5(1), edisi Yudisium.

Suarjana, Nyoman \& Suwitra, I Made. (2018). Iklan Layanan Kesehatan Masyarakat (ILKM); Kajian Semiotik. Jurnal Kesehatan Terpadu, 2(2), 82-90.

Subandi. (2011). Deskripsi Kualititatif sebagai Satu Metode dalam Penelitian Pertunjukan. Harmonia, 11(2), 173-179.

Sukmadinata. (2006). Metode Penelitian Kualitatif. Bandung : Graha Aksara.

Teeuw, A. (1984). Sastra dan Ilmu Sastra: Pengantar Teori Sastra. Jakarta: Pustaka Jaya.

Sumber Internet

https://www.youtube.com/watch?v=VqmM3sKxm3Y 